$\begin{array}{ll}\text { Türkiye Tarmmsal Araştırmalar Dergisi } & \text { Turk J Agric Res } \\ \text { dergipark.gov.tr/tutad } & \text { 2017, 4(1): 89-95 } \\ \text { OTÜTAD } & \text { ISSN: 2148-2306 } \\ \text { Derleme / Review } & \text { e-ISSN: 2528-858X } \\ \text { doi: 10.19159/tutad.300720 }\end{array}$

\title{
Seralarda Yüksek Sıcaklıkların Azaltılmasında Kullanılan Yöntemler
}

\author{
Sedat BOYACI ${ }^{*}$, Adil AKYÜZ ${ }^{2}$, Sait ÜSTÜN² ${ }^{2}$ Abdullah Nafi BAYTORUN ${ }^{3}$, Özkan GÜĞERCINN ${ }^{3}$ \\ ${ }^{l}$ Ahi Evran Üniversitesi, Ziraat Fakültesi, Biyosistem Mühendisliği Bölümü, Kırşehir, TÜRKIYYE \\ ${ }^{2}$ Kahramanmaraş Sütçü İmam Üniversitesi, Ziraat Fakültesi, Biyosistem Mühendisliği Bölümü, Kahramanmaraş, TÜRKIYY \\ ${ }^{3}$ Çukurova Üniversitesi, Ziraat Fakültesi, Tarımsal Yapılar ve Sulama Bölümü, Adana, TÜRKIYYE
}

\begin{tabular}{lc}
\hline Geliş Tarihi/Received: 29.09 .2016 & Kabul Tarihi/Accepted: 10.02 .2017 \\
\hline *Sorumlu Yazar/Corresponding author: sedat.boyaci@ahievran.edu.tr &
\end{tabular}

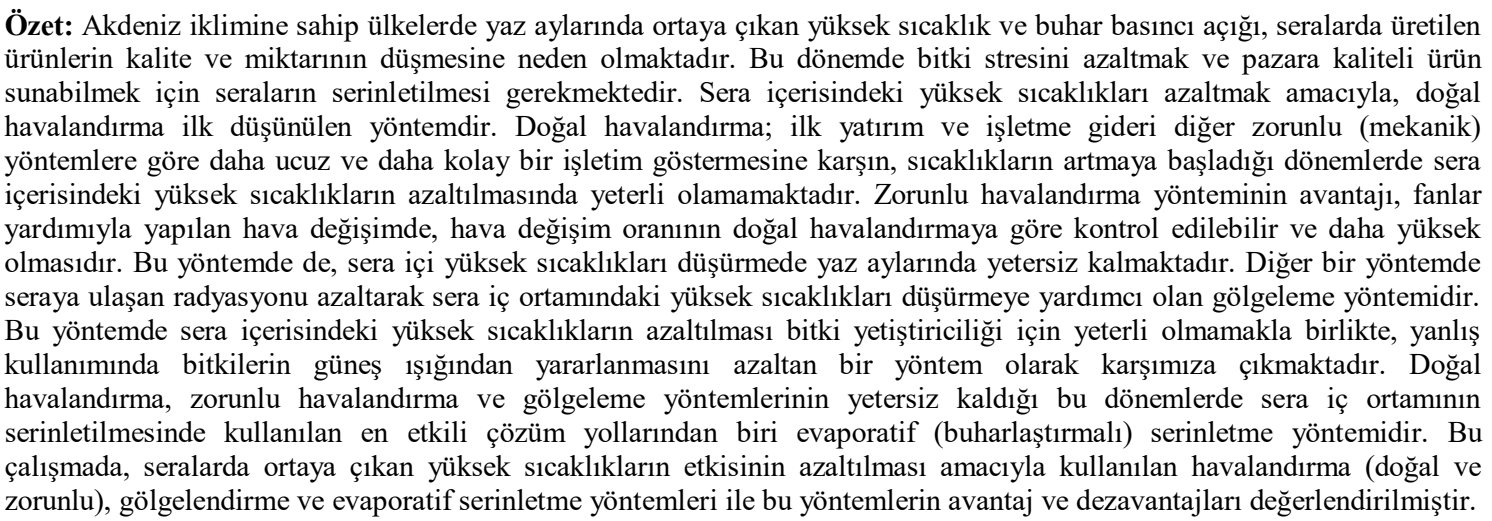

Anahtar Kelimeler: Sera, havalandırma, gölgeleme, serinletme sistemleri, evaporatif serinletme

\section{The Methods Used to Decrease High Temperatures in Greenhouses}

\begin{abstract}
Vapor pressure deficit and the high temperature emerged during the summer months in the countries with Mediterranean climate, results in decrease of the quantity and the quality of the products produced in greenhouses. During this period, to reduce the plant stress and in order to provide high quality products to the market, greenhouses are required to be cooled. In order to reduce the temperatures in greenhouse, natural ventilation is the first method considered. Although natural ventilation; is cheaper than the other forced methods in terms of the first investment and operating expenses, it is not enough to reduce the high temperatures in the greenhouse during the periods when the temperatures are starting to increase. The advantage of the forced ventilation method with fans is the higher amount of air exchange ratio and the ability to control ratio compared to natural ventilation. This method, too, is insufficient in the summer months to reduce the high temperatures inside the greenhouse. Another method is the shading method; which helps to lower high temperatures in the inside the greenhouse by reducing the radiation reaching the greenhouse. In this method, reduced temperature level inside the greenhouse is insufficient for plant growth, and also improper use of this method causes reduced use of sunlight by plants. One of the most effective solutions for cooling the greenhouse during these periods when natural ventilation, forced ventilation and shading methods are inadequate is evaporative cooling. In this study, ventilation (natural and forced), shading and evaporative cooling methods, used to reduce the effect of high temperature that occurs in greenhouses, and advantages and disadvantages of these methods have been evaluated.
\end{abstract}

Keywords: Greenhouse, ventilation, shading, cooling systems, evaporative cooling 


\section{Giriş}

Seralarda yetiştiricilik yapmanın faydalarından bir tanesi üretim ortamında bitki yetiștiriciliği için gerekli olan; 1şık, nem, sıcaklık, karbondioksit $\left(\mathrm{CO}_{2}\right)$ miktarı ve havalandırma oranı gibi çevre denetimine etki eden temel faktörlerin kontrol edilebilme imkânıdır. Bu faktörler arasında sera içerisinde bitki büyümesini etkileyen en önemli faktörlerden biri de sıcaklıktır. Sera içerisinde yetiştirilen bitki türleri, büyüme aşamalarında farklı optimum büyüme sıcaklıklarına ihtiyaç duyarlar. $\mathrm{Bu}$ sıcaklık değerlerinin artması veya azalması bitkinin verim ve kalite parametrelerine doğrudan etki etmektedir. Ilıman iklim bölgelerinde açık ve güneşli günlerde, sera ortamında güneş 1şınımından kazanılan fazla miktardaki 1sı enerjisi nedeniyle, iç ortamdaki sıcaklık değerleri bitki için gerekli olan optimum sıcaklık değerlerinin üstüne çıkabilmektedir. Bu artış bitkinin üretim ve pazarlanabilir meyve kalitesine etki etmektedir. Bu dönemlerde sera içi sıcaklık artışını kontrol etmek için; havalandırma, gölgelendirme ve soğutma yöntemlerinden biri veya birkaçı birlikte kullanılmaktadır.

Doğal havalandırma, rüzgâr ve iç-dış sıcaklık farkı etkisiyle (gravite) gerçekleşirken; zorunlu havalandırmada ise, fanlar kullanılmaktadır. Bunun yanında, farklı 1 şı geçirgenliğine sahip örtü malzemeleri ise sonbahar ve ilkbahar dönemleri gibi geçiş mevsimlerinde sera içi sıcaklıkları azaltmaya yardımcı olsa da, yaz aylarında sera içerisinde ortaya çıkan yüksek sıcaklıkları bitkilerin ihtiyacı olan optimum sınırlarda tutamamaktadırlar. $\mathrm{Bu}$ dönemlerde sera içi sıcaklıkları düşürmek amacıyla evaporatif serinletme yöntemleri kullanılmaktadır. Bu yöntemler havanın duyulur 1sısını gizli isıya çevirerek iç ortam hava sıcaklığını dış ortam hava sıcaklığının altına düşürebilen sistemlerdir.

$\mathrm{Bu}$ çalışmada; seralarda ortaya çıkan yüksek sıcaklıkların etkisinin azaltılması amaciyla kullanılan havalandırma (doğal ve zorunlu), gölgelendirme ve evaporatif serinletme yöntemleri ile bu yöntemlerin avantaj ve dezavantajları değerlendirilmiştir.

\section{Seralarda Yüksek Sıcaklıkların Azaltılmasında Kullanılan Yöntemler}

\subsection{Havalandırma}

Yüksek yaz sıcaklıkları seradan sürekli 1s1 çıkarılması ihtiyacını gerektirir. Bu durum yapının dışındaki soğuk hava ile seradaki mevcut havanın yerini almasıyla gerçekleştirilebilir. Dış hava sıcaklığı yeterince düşük ve sera içindeki sıcaklık çok yüksek değilse, sıcak havanın yukarı ve dışa doğru hareketi ile serin hava sera açıklıklarından içeri alınırken, sıcak hava pasif olarak çatı açıklıklarından serayı terk edebilir. Bu sistem; kış, ilkbahar ve sonbahar mevsimlerinde çok etkili olmasına karşın, bu sistemin kapasitesi, yaz aylarında dış hava sıcaklığının ve güneş yükünün fazla olduğu iklimler için sera içi sıcaklıkları düşürmede etkinliği sınırlı olmaktadır (Sethi ve Sharma, 2007). Havalandırmanın performans1 yalnızca sera iklimini düzenlemekle kalmaz, aynı zamanda üretimin nitelik ve miktarında önemli rol oynar (Bartzanas ve ark., 2004). Seralarda bitkisel üretim yapabilmek için yazın çeşitli önlemlerle seraların serinletilerek uygun çevre koşullarının sağlanması gerekmektedir. Sera içi çevre koşulları ise seranın iç sıcaklığının ve neminin belirli sınırlar arasında tutulmasıyla gerçekleşebilir. Bu amaçla yaz mevsiminde seraların havalandırılması, gölgelendirilmesi ve soğutulması gerekmektedir (Aydıncıoğlu, 2004).

\subsubsection{Doğal havalandırma}

Doğal havalandırmanın temeli, sera içi ve dışı arasındaki çevresel koşullar arasında rüzgarın etkisiyle ve sicaklık farkın etkisinin ortaya çıkardığı basınç farklılığıdır (Oca ve ark., 1999; Öztürk ve Başçetinçelik, 2002; Bartzanas ve ark., 2004; Yağcığlu, 2009). Bu yöntemin günümüzde kullanımının en önemli nedeni; zorunlu havalandırma yöntemlerine göre daha az enerji, ekipman ve güce ihtiyaç göstermesidir. Doğal havalandırmada kullanılan enerji miktarı zorunlu havalandırmaya göre çok az olmasına karşın, sera içerisindeki iklimsel kontrolü daha zor hale getirmektedir (Oca ve ark., 1999). Solar radyasyon düzeyinin yüksek olduğu dönemlerde doğal havalandırma ile seralar genellikle yüksek sıcaklık değerlerine ulaşır (Kittas ve ark., 2001). Sicaklıkların yükseldiği bu dönemlerde doğal havalandırmanın etkin kullanılabilmesi için yan duvar ve çatı havalandırma açıklıklarının taban alanına oranı ve bunların kombinasyonlarının konusunda birçok çalışma yapılmış ve günümüzde de bu araştırmalar devam etmektedir.

Seralarda en etkin doğal havalandırma çatı ve yan havalandırmanın birlikte kullanıldığ 1 durumlarda elde edilebilmektedir. $\mathrm{Bu}$ sayede seralarda önemli bir sorun olan yüksek nem azaltılabilir ve böylece bitkiler daha uzun ömürlü ve sağlıklı gelişebilir (Demir ve ark., 1998; Baytorun ve ark., 2000). Bunun yanında rüzgâr hızının yüksek olduğu bölgelerde havalandırma kapaklarının yan duvarlara monte edilmesi veya çatı havalandırması mevcut ise emme yüzeyindeki kapaklar hafif açılması gerekirken, tek olarak yapılan seralarda yapım maliyetini düşürmek amacıyla yan duvar havalandırmasından vazgeçip 
çatıda \% 25 oranındaki bir açıklığın yapılmasını gerekmektedir (Baytorun, 1989). Baytorun ve ark. (1994), nem oranı yüksek hareketsiz bir havanın seralarda özellikle mantari hastalıklara neden olacağ 1 ve serada iyi bir havalandırma için, havalandırma açıklıklarının sera taban alanının \% 20'si kadar olması gerektiğini belirtirken; bu oran Nicolaus (1990) tarafindan, \% 25; Özmerzi ve Kürklü (1989) tarafından ise, sadece çatı havalandırmas1 yapiliyor ise toplam pencere alanının sera taban alanının \% 33'ü; Sevgican (1989), çatıdaki havalandırma açıklığı alanı taban alanının \% 16-20'si oranında, kenarlarındaki havalandırma açıklıklarının alanı ise bu oranın yarısı kadar olması gerektiği, aksi halde, sıcak günlerde sera içi yüksek sıcaklığını düşürmenin mümkün olmadığı belirtilmiştir. Zabeltitz (1990) ise, Akdeniz iklim kuşağının egemen olduğu seralarda, havalandırma açıklığı alanının sera taban alanına oranının \% $18-25$ arasında olması gerektiğini belirtmiştir.

Harmanto ve ark. (2006), havalandirma açıklığının, toplam açıklığın \% 20'sine azaltılması durumunda, sera iç ortam sıcaklığı ürün olması durumunda $1.5^{\circ} \mathrm{C}$, boş olması durumunda ise 4.5 ${ }^{\circ} \mathrm{C}$ arttığını bildirmişlerdir. Çalışma sonucunda, tropik koşullar için tasarımlanmış olan bir serada, taban alanına kıyasla havalandırma açıklığ oranının en az \% 60 olması gerektiği belirlenmiştir. Coelho ve ark. (2006); havalandırma açıklıkları, çatı ve yan kenarlarda $\left(\mathrm{S} 1, \mathrm{~A} 1=21.3 \mathrm{~m}^{2}\right)$ ve sadece çatıda $(\mathrm{S} 2, \mathrm{~A} 2=12.3$ $\mathrm{m}^{2} ; \quad \mathrm{S} 3, \quad \mathrm{~A} 3=7.9 \quad \mathrm{~m}^{2}$ ve $\mathrm{S} 4, \quad \mathrm{~A} 4=4.4 \quad \mathrm{~m}^{2}$ ) tasarımlanmış dört farklı durumu incelemişlerdir. Çalışma sonucunda, serada iç ve diş ortam arasındaki sicaklık fark1 $3.3{ }^{\circ} \mathrm{C}(\mathrm{S} 1, \mathrm{~A} 1)$ ve $10.6{ }^{\circ} \mathrm{C}$ (S4, A4) arasında değişmiştir. Buna göre çatı ve yan duvar havalandırmasının birlikte kullanılması durumunda iç-dış sıcaklık farkının daha düşük olduğu belirlenmiştir.

\subsubsection{Zorunlu havalandırma}

Sera içi ve dışındaki sıcaklık farkının ve rüzgâr etkisinin yeterli olmadığı yörelerdeki seralarda, havalandırma işleminden beklenen sonuç doğal havalandırmayla sağlanamaz. $\mathrm{Bu}$ nedenle, sera havasının vantilatör veya aspiratör gibi zorlayıcı bir düzenekle hareketlendirildiği zorunlu havalandırma uygulamalarına ihtiyaç duyulur. Sera havası genellikle aspiratörlerle emilip dışarı atılırken; dış hava, giriş açıklıklarında yönlendirilerek içeri alınır. Zorunlu havalandırmayla havalandırılan seraların çoğunda, doğal havalandırma pencerelerine de yer verilir. Sera içi sıcaklık arttıkça, önce çatı pencereleri, yetmezse daha sonra yan pencereler açılır. $\mathrm{Bu}$ işlem sonunda istenen sonuca ulaşılamazsa, doğal havalandırma pencereleri kapatılır, fanlar çalıştırılarak zorunlu havalandırmaya geçilir (Yağcığlu, 2009). Seralarda yeterli havalandırma sağlanması için $\mathrm{Z}=60 \quad \mathrm{~h}^{-1}$ olmalıdır. Serada dakikada bir hava değişimi $\left(\mathrm{Z}=60 \mathrm{~h}^{-1}\right)$ olması durumunda, iç ortam sıcaklığg dış ortam sıcaklığından $5{ }^{\circ} \mathrm{C}$ daha yüksektir. İç ve diş ortam arasındaki sıcaklık farkının $5{ }^{\circ} \mathrm{C}$ olması genellikle uygun olduğundan, serada dakikada bir hava değişimi olması önerilir (Baytorun, 1989). Seralarda en düşük havalandırma oranı olarak, genellikle dakikada 3/4-1 hava değişimi önerilir. Sera iç ortam sıcaklığındaki artış, hava akışıyla ters orantılıdır. Güneşli bir günde hava değişim oranının 3/4 olması durumunda, sera iç ortamında sıcaklık artışı yaklaşık $6{ }^{\circ} \mathrm{C}$ 'dir. Bununla birlikte, hava değişim oranının dakikada 1 olması durumunda, sıcaklık yaklaşık $5{ }^{\circ} \mathrm{C}$ olacaktır (Öztürk ve Başçetinçelik, 2002).

\subsection{Gölgeleme}

Örtü materyalinden sera içerisine giren solar radyasyon seralarda ısı kazancının ana kaynağıdır. Gölgelendirmenin amac1, arzu edilmeyen güneş ışınlarının sera içine girmesini engelleyerek sera içindeki hava sıcaklığının düşürülmesidir. $\mathrm{Bu}$ amaçla yapılan çalışmalarda, Shukla ve ark. (2008) sera içerisine kurdukları 1sı perdeleri ile sera içi sıcaklığın diş ortama göre $5{ }^{\circ} \mathrm{C}$ düştüğünü belirlemişlerdir. Bailey (1981), alüminyum gölgeleme materyali kullandığı çalışmasında sera içi sıcaklığı kontrol serasına göre dış hava sicaklığının $33 \quad{ }^{\circ} \mathrm{C}$ olduğu durumda $\quad 6 \quad{ }^{\circ} \mathrm{C}$ düşürmüştür. Sethi ve Gupta (2004) polietilen ile örtülü serada alüminyum polyester gölgeleme materyali kullandıkları çalışma sonucunda; günlük ortalama solar radyasyon ve ortalama hava sıcaklığını, kontrol serasına göre sirasıyla \% 43 ve 3-4 ${ }^{\circ} \mathrm{C}$ düşürmüștür. Abdel-Ghany ve ark. (2012); seralarda yakın kızıl ötesi radyasyonu (NIR) yansitan örtü materyalinin seralarda $5{ }^{\circ} \mathrm{C}$ 'den daha fazla sıcaklığı düșürmediğini ve bu sicaklık düşüşünün yaz aylarında sıcaklığın $45{ }^{\circ} \mathrm{C}$ 'nin üzerinde olduğu bölgelerde yetersiz olduğunu belirterek, bu materyalin geliştirilmesine ihtiyaç olduğunu bildirmişlerdir.

Ghosal ve ark. (2003) sera dış yüzeyindeki gölgeleme örtüsü üzerinde film şeklinde su akışıyla nemlendirmeli serinletme uygulamışlardır. Çalışma sonucunda; gölgeleme uygulanmayan koşullarla karşılaştırıldığında, seradaki hava sıcaklığı su filmi akışıyla $6{ }^{\circ} \mathrm{C}$ ve gölgeleme uygulamasıyla $2{ }^{\circ} \mathrm{C}$ azaldığı; dış ortam sıcaklığıyla karşıllaştırıldığında, gölgeleme uygulanan koşullarda su akışıyla $3{ }^{\circ} \mathrm{C}$ azalma sağlandığ 1 belirlenmiştir. 


\subsection{Evaporatif serinletme sistemleri}

Sera içerisindeki iklim koşullarının hafifletilmesi için en etkili çözüm yollarından biri evaporatif serinletme sistemlerinin kullanılmasıdır. $\mathrm{Bu}$ sistemin çalışma prensibinin temelinde hissedilir ısının gizli ısıya dönüşmesi vardır. Bunun için sera ortamına su doğrudan sisleme yağmurlama ile veya sslak pedler ile verilir. Evaporatif serinletme eş zamanlı olarak sıcaklık ve buhar basıncı açığını düşürür ve sera iç sıcaklığının dış hava sıcaklığından daha düşük olmasını sağlar (Cohen ve ark., 1983; Arbel ve ark., 1999; Willits, 1999).

\subsubsection{Fan-ped sistemi}

Fan-ped sistemi için kabul edilen yöntem bir duvara fanlar, karşı kenara da pedlerin yerleştirilmesidir. Dışarıdaki hava sera içerisine sslak pedden geçerek çekilir ve böylece hava nemlendirilerek serinletilir. Islak pedden geçen bu hava sera içerisindeki karşı kenarda bulunan fanlar yardımıyla çekilir. Böylece sera içerisinde aşırı isı birikimi olmaz. Bu yöntemin avantajı; sistemin işletim kolaylığı, kontrol ve aynı zamanda yaprakların 1slanması gibi bir durum ortaya çıkarmamasıdır. Bu yöntemin dezavantajları ise; yüksek maliyet, sera içerisinde üniform bir serinletme oluşmaması ve sisleme yöntemi ile karşılaştırıldığında daha düşük bir serinletme etkisi yaratmasıdır (Arbel ve ark., 2003).

Kittas ve ark. (2003), fan-ped sistemi kullanarak yürüttükleri çalışmada, iç sıcaklık değerini dış sıcaklık değerinden $10{ }^{\circ} \mathrm{C}$ daha düşük ve sistem etkinliğini \% 80 olarak bulmuşlardır. Davies (2005) fan-ped sistemini kullanarak sera iç ortam sıcaklığını, dış ortam sıcaklığına göre $15{ }^{\circ} \mathrm{C}$ serinlettiğini ve bu sistemin diğer geleneksel serinletme sistemlerine göre $5{ }^{\circ} \mathrm{C}$ kadar farkla daha iyi bir serinletme etkinliğine sahip olduğunu belirtmiştir. Fuchs ve ark. (2006), fan-ped kullanarak yaptıkları çalışmada bitki sıcaklığında 2 ${ }^{\circ} \mathrm{C}$ azalma belirlerken, sera içi sıcaklığını dış sıcaklığa göre $15{ }^{\circ} \mathrm{C}$ düşürmeyi başarmışlardır. Baytorun ve ark. (1994), seralarda yapılan doğal havalandirma ile $2{ }^{\circ} C^{\prime}$ lik sicaklık fark 1 sağlanırken, gölgeleme+havalandırma önlemlerinin birlikte alınması durumunda ise iç sıcaklığı dış sicaklık değerine kadar düşürülebilmişlerdir. Bunun yanında seralarda evaporatif soğutma (fan-ped) yapılmış, dış oransal nem ve vantilatör sayısına bağlı olarak iç dış sıcaklık değerinin $8 \quad{ }^{\circ} C^{\prime}$ nin altına düşürülebileceğini bildirmişlerdir.

Johannes ve ark. (2009)'nın gölgeleme filesi (NET) ve fan-ped sistemini karşılaştırdıkları çalışmalarında, fan-ped sisteminde dış hava sıcaklığı ve NET sistemine göre gün içerisinde ortalama hava sicaklığ ${ }_{1} 2.6-3.2^{\circ} \mathrm{C}$, gece ise 1.2-2.3 ${ }^{\circ} \mathrm{C}$ azalmıştır. Maksimum sıcaklıkta ise fan-ped sisteminde ortalama $4{ }^{\circ} \mathrm{C}$ düşüş yaşanmıştır. Bitki su tüketiminde ise fan-ped sisteminde günlük su tüketimi bitki başına $1.21 \mathrm{iken}$, net sisteminde 1.81 bulunmuş ve fan-ped sisteminin bitkiden olan buharlaşma kaybını azalttığı görülmüştür. Toplam domates üretiminde ise; net sisteminde bitki başına verim $6.4 \mathrm{~kg}$ iken, fan-ped sisteminde $6.3 \mathrm{~kg}$ olarak bulunmuştur. Pazarlanabilir ürün açısından ise net sisteminde bitki başına verim $4.5 \mathrm{~kg}$, fanped sisteminde ise $3.8 \mathrm{~kg}$ olarak bulunmuştur. Fanped sisteminde yüksek oranda meyvelerde çatlama, düşük oranda çiçeklenme ve kök gelişimi saptanmıştır. Yapılan çalışma sonucunda; fan-ped sisteminde oransal neme dikkat edilmesi gerektiği, aksi takdirde ürün kayıplarının yaşanacağ belirtilmiştir.

\subsubsection{Sisleme sistemi}

Sisleme yöntemiyle serinletmede, sera içinde bitkilerden itibaren yeterli bir yükseklikten sera boyunca geçirilen boruların üzerine yerleştirilen püskürtme memeleriyle yapılmaktadır. $\mathrm{Bu}$ yöntemin öncelikli amacı; sera havasının nemlendirilmesi olmakla beraber, bitkilerin serinletilmesi ve hatta sulanması işlevleri için de kullanılmaktadır (Öztürk ve Başçetinçelik, 2002). Sisleme yaparak serinletme sisteminde düşük ve yüksek basınçlı olmak üzere iki yöntem vardır. Bunlardan düşük basınçlı olanı 300-400 kPa basınç arasında çalışır ve 50-100 $\mu \mathrm{m}$ arasında orta hacimli damla çapları üretir. Yüksek basınçlı sistemlerde ise, 3.5-7.0 MPa basınç arasında çalışır ve 2-60 $\mu \mathrm{m}$ arasında damla çapları üretirler. Yüksek basınçlı sistemler düşük basınçlı sistemlere göre daha ince damlacıklar ürettiklerinden, daha hılı buharlaşma olur ve serinletme oranı artar (Li ve Willits, 2008).

Li ve Willits (2008), yüksek ve düşük basınçların karşılaştırıldığı çalışma sonunda; ortalama buharlaşma etkinliğini yüksek basınçlı sistemde, düşük basınçlı sisteme göre \% 64; soğutma etkinliğini ise, \% 28 daha fazla olduğunu bulmuşlardır. Öztürk (2003) tarafindan seralarda kullanılan sisleme sisteminin etkinliğinin belirlenmesi amacıyla yürütülen çalışmada; araştırma sonuçlarına bağlı olarak, sisleme sisteminin iç ortam hava sıcaklığını dış ortamdan $6.6{ }^{\circ} \mathrm{C}$ daha düşük sicaklikta tutabileceği belirlenmiştir. Montero ve ark. (1994) gölgeleme oranı \% 45 olan gölgeleme materyali ile sisleme sistemi kombinasyonunu kullandığı çalışmasında, kontrol serasına göre güneşli günde maksimum sıcaklık azalmasını $5{ }^{\circ} \mathrm{C}$ olarak bulmuşlardır. Arbel ve ark. (1999), yüksek basınçlı sisleme 
sistemi ile fan-ped sisteminin etkinliğini araştırdıkları çalışmalarında, sisleme sisteminin fan-ped sistemine göre ortam sıcaklığın $15{ }^{\circ} \mathrm{C}$ daha fazla düşürdüğünü ve bağıl nemi de \% 20 daha fazla arttırdığını bildirmişlerdir. Dağtekin ve ark. (1997), düşük basınçlı sisleme ve fan-ped sistemini karşılaştırdıkları çalışmalarında; fan-ped sisteminin kontrol bölmesine göre ortam hava sıcaklığını 8.0-10.5 ${ }^{\circ} \mathrm{C}$, düşük basınçlı sisteminin ise $3.0-4.5{ }^{\circ} \mathrm{C}$ arasında bir sıcaklık düşüşü sağladığını; hava sıcaklığının $\quad 38-40 \quad{ }^{\circ} \mathrm{C}$ 'ye yükseldiği koşullarda, düşük basınçlı sistemin ortam sicaklığını düşürmede yetersiz kaldığını belirtmişlerdir.

Erbil (2010) seralarda yaz koşullarında fan-ped sisteminin etkinliğini araştırdığı çalışmasında, dış sıcaklığın $40.5^{\circ} \mathrm{C}$ olarak ölçüldüğü günde kontrol serasındaki iç sıcaklık değeri $45{ }^{\circ} \mathrm{C}$ ölçülmüştür. Araştırmanın yürütüldüğü sera ile kontrol serasındaki ortalama sicaklık farkı 9-17 ${ }^{\circ} \mathrm{C}$ arasında değişim göstermiştir. Boyacı (2014) doğal havalandırma yapılan serada; sera içi sıcaklık değerleri, dış sıcaklık değerinden $10{ }^{\circ} \mathrm{C}$ yüksek değerlere ulaşmış ve deneme süresince sera içi ortalama sıcaklık değerleri dış sıcaklık değerinden yüksek bulunmuştur. D1ş oransal nemin \% 16 olduğu durumda sisleme+doğal havalandırma uygulamasında ulaşılan iç diş sıcaklık farkı 7.64 ${ }^{\circ} \mathrm{C}$, fan-ped uygulamasında $14.09{ }^{\circ} \mathrm{C}$ bulunmuştur. Buna göre bitki başına verim değeri olarak fan-ped sisteminde doğal havalandırma yapılan seraya göre $3 \mathrm{~kat}$, sisleme+doğal havalandırma yapılan seraya göre ise 1.7 kat verim değeri elde edilmiştir.

\subsubsection{Sera çatısından yapılan serinletme}

Sulama veya yağmurlama ekipmanlarıyla sera çatısından su akışı sağlanarak yapılan serinletme yöntemidir. Çatıdan su akışı nedeniyle örtü malzemesinin sıcaklığı azalırken, su güneş ışınımını soğurduğundan, sera içerisine ulaşan güneş ışınımı azalır ve sera iç ortamında güneş ışınımından daha az 1Sı kazanılır (Öztürk ve Başçetinçelik, 2002). Bu yöntem ile yapılan çalışmalarda, Sethi ve Sharma (2007) nin bildirdiğine göre, Mannan ve Cheema (1981) cam üzerine yapılan yağmurlamada, sera çatısının içerisinde sicaklık kontrol serasına göre $10{ }^{\circ} \mathrm{C}$ düşük iken, iç ortam havasında 5-6 ${ }^{\circ} \mathrm{C}$ arasında sıcaklık düşüşü tespit etmişlerdir. Sutar ve Tiwari (1995) PE serada çatıdan su akışının kontrol serasına göre iç ortam hava sıcaklığının 4-5 ${ }^{\circ} \mathrm{C}$ düşürdüğünü bulmuşlardır. Bunun yanında sera çatısı üzerine gölgeleme materyali ile birlikte su akışı sağlandığı zaman, kontrol serasına göre yaklaşık $10{ }^{\circ} \mathrm{C}$ sıcaklık düşüşü belirlemişlerdir. Willits ve Peet (2000), seraya diştan gölgeleme materyali kullanarak yaptıkları çalışmalarında; yalnızca gölgeleme materyalinin sera içi sıcaklığ 1 dış sıcaklığa göre \% 18 düşürdüğü, gölgeleme materyalinin sslatılması durumunda bu oranın \% 40 olduğu belirlenmiştir.

\section{Yöntemlerin Avantaj ve Dezavantajları}

Zorunlu havalandırma sistemlerine göre kurulum ve işletme maliyetinin düşük olması nedeniyle doğal havalandırma seralarda yaygın olarak kullanılan havalandırma yöntemidir. Sistemin bu avantajının yanında iç ve dış ortam arasındaki sıcaklık ve rüzgâr farkına bağlı olarak çalışması nedeniyle sistemde sıcaklık ve rüzgârın imkân verdiği ölçüde başarı düzeyi yakalanmaktadır. Araştırmacıların doğal havalandırma etkinliğini belirlemek ve arttırmak amaciyla yaptıkları çalışmalar neticesinde, etkili bir serinletme için havalandırma açıklığı alanının taban alanının $\% \quad 15-30 \quad$ arasında olması gerektiğini belirlemişlerdir. Havalandırma açıklık alanlarının toplamının \% 30'dan fazla olması durumunda ise, serinletme etkinliği üzerindeki etkisi çok düşük olmaktadır. Doğal havalandırma yöntemi; sonbahar ve ilkbahar gibi geçiş mevsimlerinde etkin bir şekilde kullanılsa da, yaz aylarında sıcaklıkların $35^{\circ} \mathrm{C}$ ve üzeri olduğu bölgelerde sera içi sıcaklıkları düşürmede etkisiz kalmaktadır. Bu durumda sera içerisinde yetiştirilen bitkilerin ihtiyacı olan optimum sıcaklık sinırların üzerine çıkarak, bitkinin çiçeklenme ve meyve bağlamasına olumsuz etki etmekte ve dolayısıyla ürün kayıplarına neden olmaktadır.

Zorunlu havalandırma yapılan seralarda havalandırma fanlar ile yapıldığından kurulum ve işletme maliyetleri doğal havalandırmaya göre daha fazladır. Ancak sistemin avantaji; fanlar yardımıyla yapılan hava değişiminde, hava değişim oranının doğal havalandırmaya göre kontrol edilebilir ve daha yüksek olmasıdır. Hava değişim oranına bağlı olarak ulaşılan sera içi sicaklık değerleri en fazla $5-6{ }^{\circ} \mathrm{C}$ civarında azaltılabilmektedir. $\mathrm{Bu}$ yöntemde de, sera içi sıcaklıkları düşürmede yaz aylarında yetersiz kalmaktadır.

Gölgeleme, yaz aylarında sera içerisine giren yüksek solar radyasyonu azaltarak sera içi sıcaklıkların düşürülmesinde kullanılan ucuz ve etkili bir serinletme yöntemidir. $\mathrm{Bu}$ sistemde gölgeleme ve yansıtma amaciyla farklı gölgeleme oranlarında materyaller, su filmi, isı perdeleri, sıv1 köpük gibi alternatif birçok materyal kullanılmaktadır. Gölgeleme ve yansıtma amacıyla kullanılan materyaller ile sera içi sıcaklıkları yaklaş1k $6{ }^{\circ} \mathrm{C}^{\prime}$ ye kadar düşürmek mümkün olsa da, bu sistemde de sicaklıkların yüksek olduğu 
dönemlerde sera içi yüksek sıcaklıkların bitkinin isteği olan optimum sınırlarda tutulamamaktadır.

Fan-ped sistemi kurulum ve işletme maliyeti; diğer uygulamalara göre daha fazla olan, ancak, sera içi sıcaklıkları düşürmede diğer yöntemlere göre çok daha başarılı bir yöntemdir. Havanın duyulur 1sısını gizli ısıya dönüştüren bu sistemde, sera içi sıcaklığını dış ortam sıcaklığına göre 15 ${ }^{\circ} \mathrm{C}$ 'ye kadar düşürmek mümkündür. Uygun işletilen fan-ped sisteminde serinletme etkinliği $\% 80$ civarında olmaktadır. Sistemi kısıtlayan faktörlerden ilki, dış ortam havasında bulunan nemin yüksek olmasıdır. Sistemin etkinliği bağıl nem ile ters orantılıdır. İkinci olarak, sistemin yanlış kullanılması sonucu iç ortam neminin yükselerek bitkilerin mantari hastalıklara yakalanma riskidir. Bir diğer husus ise, sera içerisinde havanın kat ettiği yola bağlı olarak pedden fana doğru havanın ısınarak sera içi sıcaklığının üniform bir dağılım göstermemesidir.

Sisleme sistemi yüksek ve düşük basınçlı serinletme sistemleri olarak ikiye ayrılmaktadır. Düşük basınçlı sistemler daha büyük çaplı parçacıklar ürettiğinden ve bitkilerin ıslanmasına neden olduğundan küçük damlalar üreten yüksek basınçlı sistemlere göre serinletme açısından daha az tercih edilen sistemdir. Yüksek basınçlı sistemler ile sera içi sıcaklık değerleri yaklaşık 8 ${ }^{\circ} \mathrm{C}$ 'ye kadar düşürülebilmektedir. Bunun yanında fan-ped sistemine göre daha üniform bir sicaklık dağılımı ve nem düzeyi sağlamaktadır. Fan-ped sisteminde olduğu gibi bu sistemlerde de, iç bağ 1 nem değerlerinin bitkinin isteği olan optimum sınırlar arasında tutulmasına dikkat edilmelidir.

Sera çatısından yapılan serinletmede sera içi sıcaklık değerleri dış ortam hava sıcaklığına göre $5-6{ }^{\circ} \mathrm{C}$ daha düşüktür. $\mathrm{Bu}$ sistemde başarı düzeyi fan-ped ve sisleme kadar yüksek değildir. Bunun en büyük nedeni, buharlaşan suyun sera ortamı ile temas etmemesidir.

\section{Sonuçlar}

Seralarda sıcaklıkların yükseldiği dönemlerde iç ortam sıcaklığını bitkinin istediği optimum sınırlarda tutabilmek amacıyla geliştirilen yöntemlerin değerlendirildiği çalışma sonucunda; ülkemizde enerji maliyetlerinin yüksek, ürün fiyatlarının düşük olması nedeniyle, sistem etkinliğinin yanında seçilecek serinletme yöntemlerinin yörenin iklim koşulları, enerji maliyetleri, kurulum ve işletim giderlerinin dikkate alınarak en uygun serinletme sistemi veya sistem kombinasyonlarının seçilmesinin üretici ekonomisi açısından çok önemli olduğu belirlenmiştir.

\section{Kaynaklar}

Abdel-Ghany, A.M., Al-Helal, I.M., Alzahrani, S.M., Alsadon, A.A., Ali,I.M., Elleithy, R.M., 2012. Covering materials in corporating radiationpreventing techniques to meet greenhouse cooling challenges in arid regions: A review. The Scientific World Journal, 1: 1-11.

Arbel, A., Barak, M., Shklyar, A., 2003. Combination of forced ventilation and fogging systems for cooling greenhouses. Biosystems Engineering, 84(1): 45-55.

Arbel, A., Yekutieli, O., Barak, M., 1999. Performance of a fog system for cooling greenhouses. Journal of Agricultural Engineering Research, 72(2): 129-136.

Aydıncıŏglu, M., 2004. Model bir seranın iklimlendirilmesi ve otomasyonu. Yüksek lisans tezi, Yüzüncü Y1l Üniversitesi Fen Bilimleri Enstitüsü, Van.

Bailey, B.J., 1981. Energy conservation in glasshouse using thermal screens in energy for industry. Pergamon Press, London.

Bartzanas, T., Boulard, T., Kittas, C., 2004. Effect of vent arrangement on windward ventilation of a tunnel greenhouse. Biosystems Engineering, 88(4): 479-490.

Baytorun, A.N., 1989. Doğal olarak havalandırılan seralarda havalandırma açıklıklarının belirlenmesi. III. Ulusal Kültürteknik Kongresi, Bildiriler Kitab1, 20-23 Eylül, İzmir, s.538-550.

Baytorun, A.N., Tokgöz, H., Üstün, S., Akyüz, A., 1994. Seralarda iklimlendirme olanakları. 3. Soğutma ve Iklimlendirme Kongresi, Bildiriler Kitab1, 4-6 Mayıs, Adana, s. 303-313.

Baytorun, A.N., Zaimoğlu, Z., Akyüz, A., 2000. Seralarda iklimlendirme. 2. Uluslararası Turfanda Şurası, Bildiriler Kitabı, 28-29 Nisan, Mersin, s. 112.

Boyacı, S., 2014. Kahramanmaraş yöresi için plastik seralarda uygun serinletme sisteminin belirlenmesi. Doktora tezi, Kahramanmaraş Sütçü İmam Üniversitesi Fen Bilimleri Enstitüsü, Kahramanmaraş.

Coelho, M., Baptista, F., Fitas Da Cruz, V., Garcia, J.L., 2006. Comparison of four natural ventilation systems in a Mediterranean greenhouse. Acta Horticulture (ISHS), 719(1): 157-164.

Cohen, Y., Stanhill, G., Fuchs, M., 1983. An experimental comparison of evaporative cooling in a naturally ventilated glasshouse due to wetting the outer roof and inner crop soil surfaces. Agricultural Meteorology, 28(3): 239-251.

Dağtekin, M., Gürdil, G.A.K., Yıldız, Y., 1997. Çukurova koşullarında buharlaşma ile serinletme sistemlerinde (fan ped) kullanilacak uygun malzemenin belirlenmesi. Tarımsal Mekanizasyon 17. Ulusal Kongresi, Bildiriler Kitabı, 17-19 Eylül, Tokat, s. 17-23.

Davies, P.A., 2005. A solar cooling system for greenhouse food production in hot climates. Solar Energy, 79(6): 661-668. 
Demir, Y., Uzun, S., Cemek, B., Özkaraman, F., 1998. Samsun ekolojik koşullarında farklı havalandırma açıklıklı plastik seralarda çevre faktörlerinin incelenmesi. Ondokuz Mayls Üniversitesi Ziraat Fakültesi Dergisi, 13(2): 87-103.

Erbil, F.G., 2010. Seralarda yaz koşullarında fan-ped sisteminin etkinliğinin araştırılması. Yüksek lisans tezi, Süleyman Demirel Üniversitesi Fen Bilimleri Enstitüsü, Isparta.

Fuchs, M., Dayan, E., Presnov, E., 2006. Evaporative cooling of a ventilated greenhouse rose crop. Agricultural and Forest Meteorology, 138(1-4): 203-215.

Ghosal, M.K., Tiwari, G.N., Sirivastava, N.S.L., 2003. Modeling and experimental validation of a greenhouse with evaporative cooling by moving water film over external shade cloth. Energy and Buildings, 35(8): 843-850.

Harmanto, H., Tantau, J., Salokhe, V.M., 2006. Optimization of ventilation opening area of a naturally ventilated net greenhouse in a humid tropical environment. Acta Horticulturae (ISHS), 719(1): 165-172.

Johannes, F.J., Max, W.J.H., Urbanus, N., Mutwiwa, H.J.T., 2009. Effects of greenhouse cooling method on growth, fruit yield and quality of tomato (Solanum lycopersicum L.) in a tropical climate. Scientia Horticulturae1, 122(2): 179-186.

Kittas, C., Bartzanas, T., Jaffrin, A., 2003. Temperature gradients in a partially shaded large greenhouse equipped with evaporative cooling pads. Biosystems Engineering, 85(1): 87-94.

Kittas, C., Katsoulas, N., Baille, A., 2001. Influence of greenhouse ventilation regime on the microclimate and energy portioning of a rose canopy during summer conditions. Journal of Agricultural Engineering Research, 79(3): 349-360.

Li, S., Willits, D.H., 2008. Comparing low-pressure and high-pressure fogging systems in naturally ventilated greenhouses. Biosystems Engineering, 101(1): 6977.

Montero, J.I., Anton, A., Beil, C., Franquet, A., 1994. Cooling of greenhouses with compressed air fogging nozzles. Acta Horticulture, 281(1): 199-209.

Nicolaus, A., 1990. Ventilation methodologies in greenhouses. Acta Horticulturae, 263(1): 299-306.
Oca, J., Montero, J.I., Crespo, D., 1999. A Method for studying natural ventilation by thermal effects in a tunnel greenhouse using laboratory-scale models. Journal of Agricultural Engineering Research, 72(1): 93-104.

Özmerzi, A., Kürklü, A., 1989. Seralarda havalandırma yöntemleri ve zorunlu havalandırma sistemlerinin hesaplanması. Akdeniz Üniversitesi Ziraat Fakültesi Dergisi, 2(2): 101-120.

Öztürk, H.H., 2003. Evaporative cooling efficiency of a fogging system for greenhouses. Turkish Journal of Agriculture and Forestry, 27(1): 49-57.

Öztürk, H.H., Başçetinçelik, A., 2002. Seralarda Havalandırma. Çukurova Üniversitesi Ziraat Fakültesi Yayınları: 227, Adana.

Sethi, V.P., Gupta, Y.P., 2004. Reduction of greenhouse temperature using reflector sheet. Agricultural Mechanization in Asia, Africa and Latin America, 35(2): 51-54.

Sethi, V.P., Sharma, S.K., 2007. Survey of cooling technologies for worldwide agricultural greenhouse applications. Solar Energy, 81(12): 1447-1459.

Sevgican, A., 1989. Örtüaltı Sebzeciliği. Tarımsal Araştırmaları Destekleme ve Geliştirme Vakfı, Yayın No:19, Yalova.

Shukla, A., Tiwari, G.N., Sodha, M.S., 2008. Experimental study of effect of an inner thermal curtain in evaporative cooling system of cascade greenhouse. Solar Energy, 82(1): 61-72.

Sutar, R.F., Tiwari, G.N., 1995. Analytical and numerical study of a controlled-environment agricultural system for hot and dry climatic conditions. Energy and Buildings, 23(1): 9-18.

Willits, D.H., 1999. Constraints and limitations in greenhouse cooling. Challenges for the next decade. Acta Horticulturae, 534(1): 57-66.

Willits, D.H., Peet, M.M., 2000. Intermittent application of water to an externally mounted greenhouse shade cloth to modify cooling performance. American Society of Agricultural Engineers, 43(5): 1247-1252.

Yağcioğlu, A., 2009. Sera Mekanizasyonu. Ege Üniversitesi Ziraat Fakültesi Yayınları: 562, İzmir.

Zabeltitz, C., 1990. Greenhouse construction in function of beter climate control. Acta Horticulturae, 263(1): 357-374. 